\title{
First report of a skink population in Les Saintes (Guadeloupe, FWI)
}

\section{Baptiste Angin ${ }^{1,2}$ and Régis Gomès ${ }^{2}$}

1Ardops Environnement, Pointe Allégre, 97115 Sainte Rose, Guadeloupe. ardops.environnement@gmail.com ${ }^{2}$ ASFA (Association pour la Sauvegarde et la réhabilitation de la Faune des Antilles), Morne Burat, 97180 Sainte Anne, Guadeloupe. lasfa@wanadoo.fr

Date of publication: 19 March 2015.

Citation: Angin B, Gomès R (2015) First report of a skink population on Les Saintes (Guadeloupe, FWI). Caribbean Herpetology 52:1-2.

In Guadeloupe, skink populations are known only on the islands of Desirade and Terre de Bas of Petite Terre (Breuil 2002; Lorvelec et al. 2011; Hedges \& Conn 2012; Paré \& Lorvelec 2012; Gomès \& Ibéné 2013). Another population on I'llet Cochon was listed by Henderson \& Breuil (2012), but despite great efforts by Michel Breuil (2002), S. Blair Hedges (pers. comm.), Association pour l'Etude et la protection des Vertébrés et végétaux des petites Antilles (AEVA), and Association pour la Sauvegarde et la Réhabilitation de la Faune des Antilles (ASFA), no observations have been made since its discovery in 1963. Because finding skinks, especially in low-density populations, is difficult, determining whether a species is extant or extinct is frequently impossible.

Until recently, all skink populations in Guadeloupe were assigned to a single species, Mabuya mabouya (Lacépède, 1788). Hedges \& Conn (2012) proposed a new classification recognizing five species in Guadeloupe: Mabuya desiradae on La Désirade and Petite Terre, Mabuya cochonae on I'llet Cochon, Mabuya grandisterrae on Grande-Terre, Mabuya guadeloupae on Basse-Terre, and Capitellum mariagalantae on Marie-Galante.

Les Saintes Bank is an archipelago comprised of two major islands (Terre-de-Haut and Terre-de-Bas), three islets (Grand llet, llet Cabrit, and La Coche), and additional smaller islets. All are mongoose-free (Urva auropunctata) and are the only places in Guadeloupe where endemic racers of the genus Alsophis remain abundant.

The only reference to a skink population on Les Saintes Bank was by Lazell (1973), who noted the presence of a species of skink without specifying which islands were inhabited. Breuil (2002) reported this record, adding that Lazell never saw a skink on Les Saintes Bank and was referring to an observation of a skink made by Albert Schwartz. According to Lazell and Breuil, Schwartz might have confused Terre-de-bas on Les Saintes Bank with Terre de Bas in the Petite Terre Islets, where skinks remain present at low density.

On 22 November 2014, one of us (AB) observed a skink basking on leaf litter (Fig. 1) on Terre de Haut $\left(15.86^{\circ} ;-61.58^{\circ}\right)$. When we approached, it escaped into nearby vegetation. We (AB \& GR) returned two weeks later and found five skinks in an area of 1,200 m2 (Fig. 2). Habitat is at the edge of dry forest and a clearing. Leaf litter and rocks are abundant in the forest, whereas the clearing is a composite of meadow, dense bush, and an open rocky area.

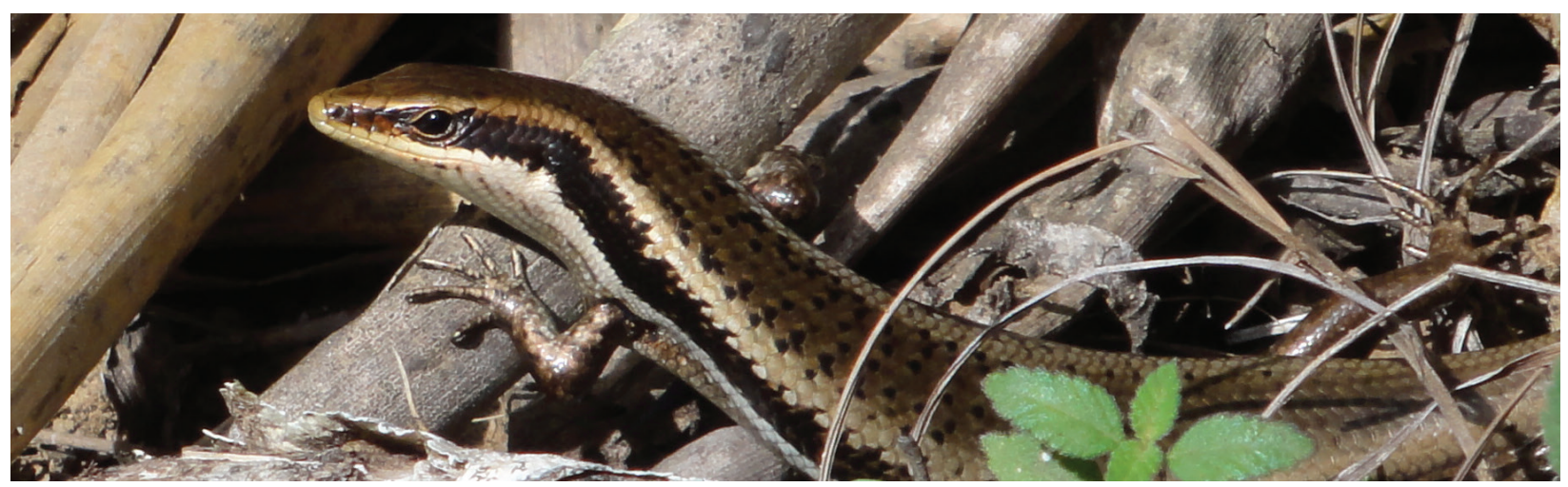

Figure 1. A skink basking on leaf litter on Terre de Haut, Les Saintes Bank, on 22 November 2014. Photo by B. Angin. 


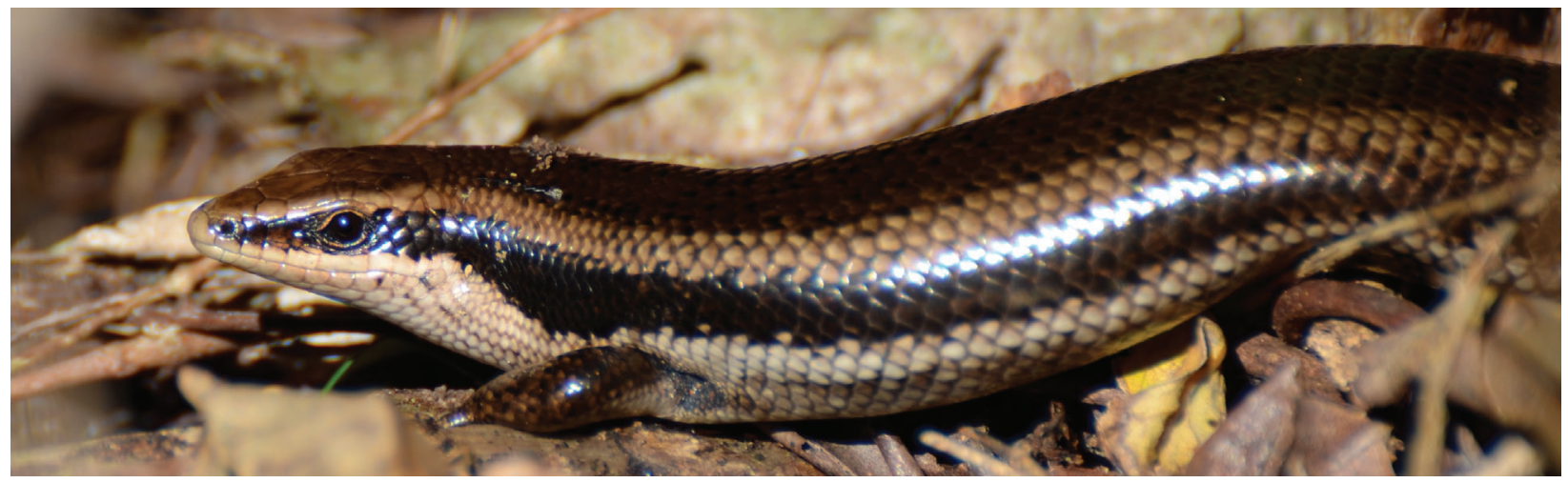

Figure 2. One of five skinks observed on Terre de Haut, Les Saintes Bank, on 5 December 2014. Photo by B. Angin.

This is the first confirmation of a skink population on Les Saintes Bank. Photographs and field observations confirm that these skinks are in the genus Mabuya. Historically, this population would be assigned to the Mabuya mabouya complex. However, the work of Hedges \& Conn (2012) suggests that it could belong to a new endemic species. This is a reasonable assumption because herpetofaunal studies on Les Saintes Bank have identified a number of bank endemics distinct from relatives on the Guadeloupean Archipelago (e.g., Alsophis antillensis and A. sanctonum, Sphaerodactylus fantasticus and S. phyzacinus, Anolis marmoratus and A. terraealtae).

\section{Acknowledgements}

We thank Beatrice Ibéné and Karl Questel for reviewing this manuscript.

\section{References}

Breuil M (2002) Histoire Naturelle des Amphibiens et Reptiles Terrestres de l'Archipel Guadeloupéen. Guadeloupe, Saint-Martin, Saint-Barthélemy. MNHN, Institut d'Écologie et de Gestion de la Biodiversité, Service du Patrimoine Naturel, Paris, Collection Patrimoines naturels, 54, 339 pp.

Gomès R, Ibéné B (2013) Mabuya desiradae (Désirade Skink). Distribution. Caribbean Herpetology, 43, 1.

Hedges, B, Conn CE (2012) A new skink fauna from Caribbean islands (Squamata, Mabuyidae, Mabuyinae). Zootaxa, 3288, 1-244.

Henderson RW, M Breuil (2012) Lesser Antilles, pp. 148-159. In: Island lists of West Indian amphibians and reptiles, Powell, R., \& Henderson, R.W. (eds.), Bulletin of the Florida Museum of Natural History, 51, 85-166.

Lazell JD (1973) The lizard genus Iguana in the Lesser Antilles. Bulletin of the Museum of Comparative Zoology, $145,1-28$.

Lorvelec O, Berchel J, Brossaud M, Pavis C (2011) Mabuya mabouya (Lesser Antillean Skink). Conservation. Caribbean Herpetology, 19, 1.

Paré T, Lorvelec O (2012) Mabuya desiradae (Désirade Skink). Conservation. Caribbean Herpetology, 38, 1. 